\title{
АЛЬТЕРНАТИВНИЙ ЗАСІБ САНАЦІї РЕЗИДЕНТНИХ НОСІЇВ ЗОЛОТИСТОГО СТАФІЛОКОКА
}

\author{
Харківський національний медичний університет
}

Роль золотистого стафрілокока в етіологічній структурі гнійно-запальних інфрекцій має особливе значення. Актуальною проблемою залишається вибір способу боротьби з бактеріоносіями. Одним з альтернативних шляхів є використання бактеріофрагів. У ході дослідження була визначена чутливість штамів Staphylococcus aureus, вилучених від студентів-медиків Харківського національного медичного універсиmemy (XНMУ), до дії бактеріофрагів різних виробників. чутливість визначали диско-дифрузійним методом до таких бактеріофрагів: стафрілофраг (ФДУП «НВО «Микроген» МОЗ РФ, випуск м. Перм), піофраг (ФДУП «НВО «Микроген» МОЗ РФ, випуск м. Нижній Новгород) і стафрілококовий бактеріофраг (фрармачевтичний завод «Біофрарм», м. Біла Церква, Україна). Результати дослідження показали, що більш ніж половина виділених uтамів S. aureus, $(68,75 \pm 6,69) \%$, були чутливими до стафрілофрага українського виробництва, до піофрага та стафрілофрага російського виробника встановлена низька чутливість - $(45,83 \pm 7,19)$ та $(22,90 \pm 6,06) \%$ відповідно.

Ключові слова: бактеріоносії, Staphylococcus aureus, бактеріофраги.

Стафрілококи залишаються одним з основних збудників гнійно-запальних захворювань різної локалізації [1]. Останні роки спостерігається розповсюдження грампозитивних мікроорганізмів, резистентних до багатьох препаратів, що ускладнює лікування гнійно-запальних інфекцій та є однією з основних проблем сучасної медицини. Рівень резистентності до деяких препаратів у ряді випадків буває настільки високим, що вони втрачають свою клінічну значимість. Особливе місце серед збудників займають метицилінрезистентні стафрілококи.

На основі багатоцентрових досліджень, проведених у США і більшості країн Європи та Росії, було підтверджено глобальне зростання метицилінрезистентних штамів стасрілококів (MRSA), особливо нозокоміальних $[2,3]$. Однак реальний рівень поширення MRSA-штамів у регіонах і в конкретних закладах в цілому залишається нез'ясованим. Моніторинг за циркуляцією штамів не лише нозокоміальних, а і позалікарняних, являється важливим завданням сучасної медицини, в тому числі і серед майбутніх медичних працівників [4].

За даними вчених, майже 40 \% людей є постійними носіями S. aureus на слизовій оболонці верхніх дихальних шляхів. Важливе клінічне значення бактеріоносійства зумовлюється типовістю процесу транслокації стасрілокока з шкірних покривів та слизової оболонки у внутрішнє середовище організму власника з розвитком широкого спектру захворювань (від легких ступенів ураження шкіри до загрозливих для життя станів: пневмонія, сепсис, синдром токсичного шоку) $[5,6]$.

Актуальною залишається розробка методів санації резидентних стафілококових носіїв з метою профрілактичних і лікувальних заходів при виникненні інфекції верхніх дихальних шляхів. Для санації доцільно застосовувати ліки, які б, з одного боку, стимулювали місцевий імунітет і природну колонізаційну резистентність слизової оболонки макроорганізму, з іншого - знижали вірулентні властивості мікроорганізму, тим самим підвищуючи еорективність лікарської дії.

Використання антибактерійних препаратів 3 метою санації майже завжди має негативні сторони, супроводжується зміною реактивності організму та порушенням видового складу нормальної мікрофрлори. Альтернативні пошуки препаратів антибактерійної дії проводилися завжди. Для профрілактики та лікування гнійно-септичних захворювань у 20-30-ті роки минулого століття досить успішно використовували бактеріофаги, однак з появою антибіотиків їх застосування припинили. Враховуючи безпечність застосування фрагових препаратів, сучасні лікарі знов повернулись до їх використання.

На сьогодні в Україні для санації бактеріоносіїв використовують комерційні бактеріофаги як українського, так і російського виробництва. Але вивчення лізуючої активності бактеріофагів різних виробників відносно штамів S. aureus, циркулюючих на території України, не проводилось. Публікації вітчизняних авторів 3 аналізу терапевтичної ефрективності тих чи інших серій бактеріоорагів також відсутні. 
Метою роботи було визначення чутливості штамів S. aureus, вилучених від студентів-медиків ХНМУ, до дії бактеріофрагів різних виробників.

\section{Матеріали і методи}

Наукову роботу проводили на базі бактеріологічної лабораторії ХНМУ. В ході дослідження було обстежено 248 студентів віком від 19 до 23 років. Об'єктом вивчення були клінічні ізоляти стасрілококів, вилучені із слизу зіва і носа студентів-медиків.

У роботі були використані мікробіологічні методи ізоляції та ідентифрікації вилучених від носіїв мікроорганізмів, згідно з діючими нормативними документами МОЗ України [7]. Клінічні штами стафрілококів ідентифікували відповідно 3 рекомендаціями 12-го видання «Визначення бактерій Берджі» за комплексом культуральних і біохімічних властивостей (STAPHY test 16, Lachema, Чехія) [8].

Чутливість виділених культур золотистого стасрілокока до оксациліну досліджували за допомогою методу стандартних дисків. Облік результатів проводили згідно з наказом № 167 [9]. Після порівняння отриманих результатів досліджувані штами відносили до метицилінрезистентних (MRSA) та метицилінчутливих (MSSA).

Чутливість виділених штамів S. aureus до бактеріофрагів визначали на середовищі Мюллера-Хінтона (HiMedia, Індія) крапельним методом [10]. Приготування суспензій мікроорганізмів із визначеною концентрацією мікробних клітин проводили за допомогою електронного приладу DensiLa-Meter (PLIVA-Lachema a.s., Чехія) по шкалі McFarland згідно з інструкцією до приладу. Після інкубації при $37^{\circ} \mathrm{C}$ протягом 18-20 год визначали ступінь лізису стафрілококів: $\mathrm{CL}$ - зливний лізис; SCL - напівзливний лізис; +++ - окре- мі негативні колонії у кількості >20; ++ - окремі негативні колонії у кількості від 10 до 20; + - окремі негативні колонії у кількості до 10, - - відсутність лізису [10]. У наших дослідженнях вважали показниками високої чутливості зони лізису CL та SCL, інші зони лізису - стійкими. Чутливість штамів стасрілокока визначали до стафрілофрага (ФДУП «НВО «Микроген» МОЗ РФ, М. Перм), піофрага (ФДУП «НВО «Микроген» МОЗ РФ, м. Нижний Новгород) та до стафрілококового бактеріофрага (фрармацевтичний завод «Біофрарм», м. Біла Церква, Україна).

\section{Результати досліджень та їх обговорення}

У ході проведеного дослідження було встановлено, що кількість виділених штамів золотистого стафілокока серед обстежених студентів складає 19,35 \%, серед них виявлено 6,25\% штамів MRSA, що узгоджується 3 даними літератури [11].

Кількість циркулюючих штамів MSSA майже в 15 разів більше, ніж штамів MRSA $(p<0,05)$ (табл. 1).

Таблиця 1

Частка штамів MSSA та MRSA, виділених від студентів-медиків

\begin{tabular}{|l|c|c|}
\hline \multirow{2}{*}{ Чутливість до метициліну } & \multicolumn{2}{|c|}{ S. aureus, $\mathrm{n}=48$} \\
\cline { 2 - 3 } & $\mathrm{n}$ & $\mathrm{M} \pm \mathrm{m}, \%$ \\
\hline MRSA & 3 & $6,25 \pm 3,49$ \\
\hline MSSA & 45 & $93,75 \pm 3,49$ \\
\hline
\end{tabular}

Далі було проведено визначення фрагочутливості штамів S. aureus до різних серій бактеріофрагів. Препарати стафілофраг і піофаг мали різну активність у межах від 22,9 до 68,7 \% (мал. 1).

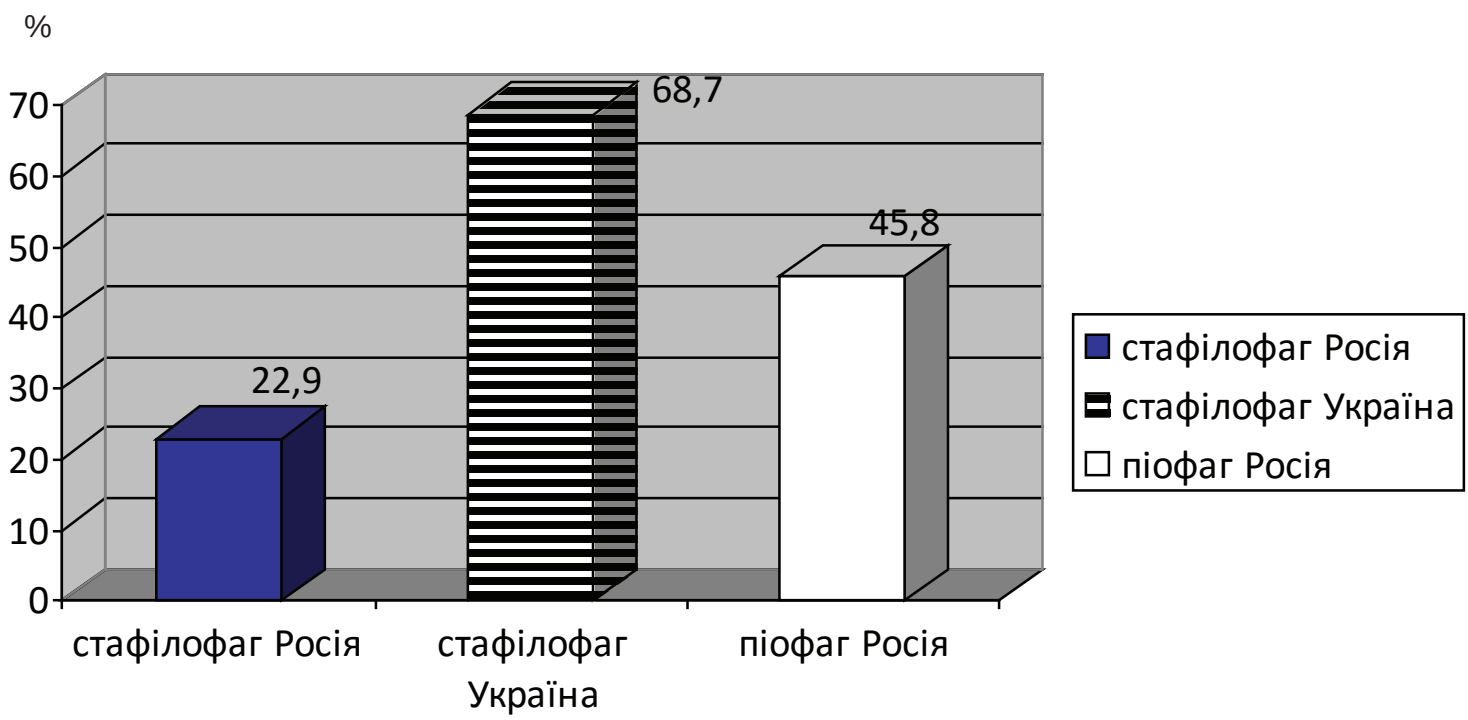

Мал. 1. Рівень чутливості штамів S. aureus до бактеріофрагів. 
Встановлено, що більш ніж половина штамів S. aureus, $(68,75 \pm 6,69) \%$, були чутливими до стасрілофрага українського виробництва, до піофрага - $(45,83 \pm 7,19) \%$ і тільки $(22,9 \pm 6,06)$ \% ізолятів мали чутливість до російського стафрілофрага.
Наступним етапом дослідження було визначення фрагочутливості штамів MRSA та MSSA до дії комерційних бактеріофрагів (мал. 2).

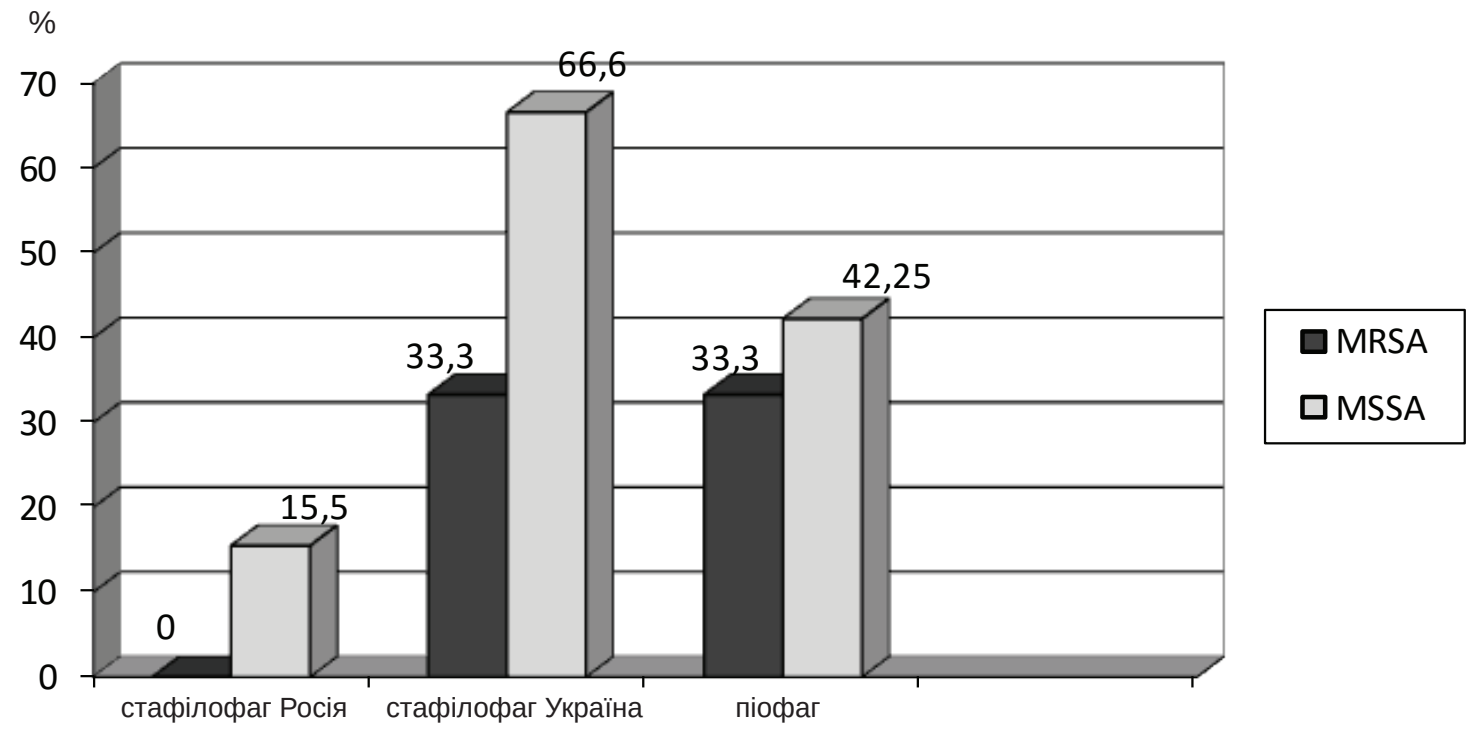

Мал. 2. Рівень чутливості штамів MRSA та MSSA до дії бактеріофрагів.

Порівняльний аналіз фрагочутливості штамів, виділених від студентів-медиків, показав, що штами MRSA мали низькі показники чутливості - 33,3 \%, в той час у штамів MSSA виявлені високі показники фрагочутливості (від 42,2 до 66,6 \%) .

Аналізуючи дані проведених досліджень, встановлено, що частота циркуляції штамів золотистого стафілокока серед майбутніх медичних працівників складає 19,4 \%. Кількість штамів MRSA серед студентів дорівнює $(6,25 \pm 3,49) \%$, що менше від циркулюючих MSSA штамів $(93,75 \pm 3,49) \%(p<0,05)$.

Результати дослідження показали, що фрагочутливість штамів S. aureus визначалась у межах від 22,9 до 68,7 \%. Чутливість штамів MRSA до піофрага та стафрілофрага українського виробництва не мала різниці й складала 33,3 \%. Чутливість штамів MSSA до піофага визначалась на рівні $(42,25 \pm 7,36) \%$, до стафрілофрага російського виробництва - $(15,50 \pm 5,40) \%$, до стафрілофага українського виробництва - $(66,60 \pm 7,03) \%$.

Таким чином, активність бактеріофрагів відносно штамів S. aureus, виділених від студентів-медиків, досить різноманітна. Найбільш ефрективним виявився бактеріофраг - стафрілофраг українського виробництва. Пояснити високу чутливість штамів S. aureus до дії бактеріофрагів можна тим, що препарат був отриманий зі штамів, які циркулюють на території України.
Безумовно, дія бактеріофрага на мікробні клітини не обмежується тільки літичним ефектом. Якщо літичного ефректу так і не відбулося внаслідок взаємодії бактерії 3 фагом, то в мікробних клітинах відбуваються інші зміни: вони більш доступні для фрагоцитозу (опсонізуюча дія бактеріофага), фріксують комплемент (амбоцепторна дія), здатні на раптову аглютинабельність (аглютинувальна дія), втрачають вірулентність і токсичність.

Видатний науковець Д'Ерель характеризував значення бактеріофрага для імунітету: «Він збуджує організм, постраждалий від інфрекції, до опору; він утворює лізини 3 опсонізуючим ефектом, він сприяє розвитку фагоцитозу та відкриває шлях до розвитку антибактерійного імунітету» [12]. Отже, дія бактеріофага може здійснюватись у двох фрормах: стерилізуюча (літична) та імунізуюча.

\section{Висновки}

1. Використання бактеріофрагів у практичній медицині має перевагу над антибіотиками за рахунок їх високої специфічності та відсутності побічної дії. Комерційні бактеріофаги можна рекомендувати як альтернативний засіб санації бактеріоносіїв з попереднім визначенням фрагочутливості штамів, виділених від пацієнтів.

2. Обмежене коло використання антибіотиків, ефективних для лікування стафрілококових інфекцій, особливо спричинених штамами MRSA, сприяє перспективному використанню бактеріофрагів для санації носіїв. 
Перспективним напрямком подальшого дослідження $€$ вивчення механізмів формування резистентності штамів S. aureus до бактеріофрагів різного походження.

\section{Література}

1. Способ санации бактерионосителей S. aureus / Л.П. Потехина, Т.М. Уткина, О.Л. Карташова, А.Ф. Зверев // Современные проблемы науки и образования. - 2012. - № 5. - С. 2-7.

2. Павлова И.Ж. Биологические свойства S. aureus, выделенных из различных локусов бактерионосителей / И.Ж. Павлова, Ю.С. Хомич // Вестник Челябинского государственного университета. - 2013. - № 7 (298). - С. 66-67.

3. Изучение антибактериального действия наночастиц меди и железа на клинические штаммы S. aureus / И.B. Бабушкина, В.В. Бородулин, Г.В. Коршунов, Д.М. Пучиньян // Саратовский мед. журн. - 2010. - Т. 6, № 1. - С. 9-14.

4. Хараева З.Ф. Особенности внутрибольничных штаммов Staphylococcus aureus / З.Ф. Хараева, Б.О. Балахова, Р.Р. Белимготова // Фундаментальные исследования. - 2014. - № 11(6). C. $1316-1318$.

5. Сидоренко С.В. Клиническое значение антибиотикорезистентных грамположительных микроорганизмов / С.В. Сидоренко // Инфрекции и антимикробная терапия. - 2003. - Т. 5, № 2. - С. 4854.

6. Страчунский Л.С. Внебольничные MRSA- новая проблема антибиотикорезистентности / Л.С. Страчунский, Ю.А. Белькова, А.В. Дехнич // Клиническая микробиологическая антимикробная химиотерапия. - 2005. - Т. 7, № 1. - С. 32-46.

7. Медицинская микробиология: Учебная литература для студ. мед. вузов / под ред. В.И. Покровского, О.К. Поздеева. - М., 1999. - С. 74-76.

8. Хулт Д. Определитель бактерій Берджи / Д. Хулт, Н. Криг, П. Снит [пер. с англ. Г.А. Заварзин]. - М.: Мир, 2001. - 800 с.

9. Основные методы лабораторных исследований в клинической бактериологии / ВОЗ, Женева. - М.: Медицина, 1994. -92 c.

10. Методические указания по микробиологической диагностике заболеваний, вызываемых энтеробактериями / С.Д. Тетеренова, В.А. Килессо, Ю.М. Крюков, М.С. Премухина. - М., 1984. $-142 \mathrm{c}$.
11. Формирование распространенности MRSA штаммов у больных с гнойно-воспалительными заболеваниями / Г.Д. Гасретова, О.М. Синькова, Т.Г. Харсеева, А.Ю. Миронов // Клин. лабор. диагностика. - 2013. - № 4. - С. 33-36.

12. Аспекты применения препаратов бактериофрагов в лечении гнойных ран / О.А. Ерещенко, Л.С. Стрельников, Г.И. Кабачный, О.П. Стрилец // Биотехнология. Биомедицинская инженерия и технология современных социальных практик: Материалы науч.практ.конф., 3-5 апр. 2009 г. - Курск, 2009. - С. 40.

\section{ALTERNATIVE WAYS OF SANATION RESIDENT CARRIER STAPHYLOCOCCUS AUREUS}

O.V. Kotsar, O.V. Kochneva, T.S. Dolhova, A.Yu. Maluchenko SUMMARY. The role of Staphylococcus aureus in the etiological structure of inflammatory infections is particularly important. The actual problem is the choice of a method of controlling bacteria carriers. One alternative way is the use of bacteriophages. The study was determined the sensitivity of Staphylococcus aureus strains, isolated from medical students of Kharkiv National Medical University, to the action of bacteriophages from various productions. This sensitivity was defined disco difuzinim method by bacteriophages such as: stafilofag (FSUE NPO "Microgen" MH RF c. Perm), piofag (FSUE NPO "Microgen" MH RF c. Nizhny Novgorod) and staphylococcal bacteriophage (Pharmaceutical Factory "Biofarm" Bila Cerkva, Ukraine). The results showed that more than half of the isolates S. aureus $(68,75 \pm 6,69) \%$ were sensitive to the stafilofag Ukrainian production to the piofag and stafilofag Russian production are low sensitivity $(45,83 \pm 7,19) \%$ and $(22,9 \pm 6,06) \%$, accordingly.

Key words: bacillicarriers, Staphylococcus aureus, bacteriophages.

Отримано 18.04.2016 р. 